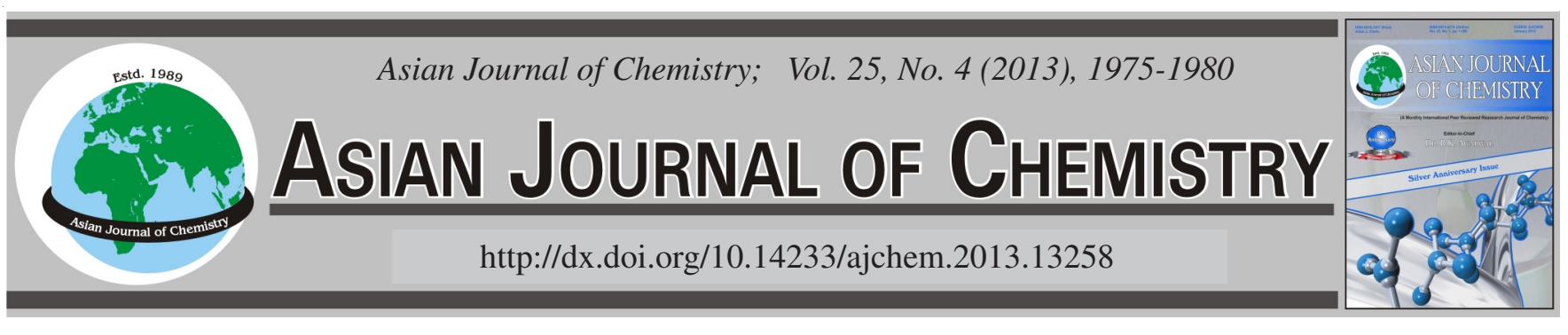

\title{
Recovery of Manganese from Spent Batteries Using Activated Carbon Powder as Reductant in Sulfuric Acid Solution
}

\author{
SAit KursunOGLU ${ }^{1, *}$ and MuAmmer KAYA ${ }^{2}$
}

${ }^{1}$ Department of Mining Engineering, Division of Mineral Processing, Abdullah Gul University, 38090 Kayseri, Turkey

${ }^{2}$ Department of Mining Engineering, Division of Mineral Processing, Eskisehir Osmangazi University, 26480 Eskisehir, Turkey

*Corresponding author: E-mail: sait.kursunoglu@agu.edu.tr

(Received: 14 December 2011;

Accepted: 10 October 2012)

AJC-12261

\begin{abstract}
Recovery of manganese from spent batteries was investigated using activated carbon powder as a reducing agent in sulfuric acid solution. The effects of four different leaching parameters (sulfuric acid concentration, amount of activated carbon powder, temperature and time) on the leaching of manganese from spent batteries were investigated using central composite design technique. The maximum manganese recovery conditions were determined as $1 \mathrm{M}$ of sulfuric acid concentration, $3 \mathrm{~g}$ of activated carbon powder, $80{ }^{\circ} \mathrm{C}$ of temperature and $3 \mathrm{~h}$ of leaching time. Under these conditions, the recovery of manganese was $86.39 \%$ and $\mathrm{pH}$ value of the solution was 0.77 . According to the reductive acid leaching results, an empirical second order equation for manganese recovery based on four investigated parameters was calculated. The observed values of manganese recoveries using model equation were found to be in a good agreement with the predicted values $\left(\mathrm{R}^{2}=0.92\right)$.
\end{abstract}

Key Words: Manganese recovery, Spent battery, Reduction, Activated carbon powder, Central composite design.

\section{INTRODUCTION}

In the last three decades, the recovery of industrially useful materials and metals in various secondary sources has been an important issue in the world. For instance, the recovery of metals from spent batteries is becoming essential due to environmental awareness and imposed regulations. Many proposed pyrometallurgical or hydrometallurgical recovery processes have been published to obtain valuable metals from the spent batteries. The some examples of pyrometallurgical process are BATREC, SNAM-SAVAN, SAB-NIFE and INMETCO ${ }^{1-3}$ and hydrometallurgical processes are BATENUS ${ }^{4}$, MODIFIED ZINCEX ${ }^{5}$, RECUPLY ${ }^{1}$ and CITRO ${ }^{2} . \mathrm{MnO}_{2}$ and $\mathrm{Mn}_{3} \mathrm{O}_{4}$ are stable in acid solution so the recovery of manganese should be carried out under reducing conditions ${ }^{6-8}$. Recently, numerous reduction methods in acid media has been investigated such as glucose reduction leaching ${ }^{9-12}$; lactose sucrose reduction leaching ${ }^{13}$; sucrose reduction leaching ${ }^{14}$ corncob reduction leaching ${ }^{8}$; oxalic acid reduction leaching ${ }^{15-18}$; citric acid and ascorbic acid reduction leaching ${ }^{19}$ and waste newspaper reduction leaching ${ }^{20}$. The use of organic reductants to leach manganese ores or secondary manganese sources was found to be very effective for manganese recovery. However, compared to organic reductants, activated carbon powder can be obtained from industrial wastes such as old carbon electrodes of electric arc furnaces, graphite blocks of oxygen furnaces, blast furnace linings, used graphite crucibles, carbon containing refractories, brake linings or brake shoes, electric motor bushes, carbon lubricant wastes and carbon fiber reinforced plastics. These wastes are cheap, plentiful and easily available. In this reduction system, activated carbon powder changes $\mathrm{MnO}_{2}$ and/ or $\mathrm{Mn}_{3} \mathrm{O}_{4}$ to $\mathrm{MnSO}_{4}$ form in sulfuric acid solution according to the following reactions ${ }^{20}$ :

$$
\begin{gathered}
2 \mathrm{Mn}_{3} \mathrm{O}_{4}+\mathrm{C}+6 \mathrm{H}_{2} \mathrm{SO}_{4} \rightarrow 6 \mathrm{MnSO}_{4}+6 \mathrm{H}_{2} \mathrm{O}+\mathrm{CO}_{2} \\
2 \mathrm{MnO}_{2}+\mathrm{C}+2 \mathrm{H}_{2} \mathrm{SO}_{4} \rightarrow 2 \mathrm{MnSO}_{4}+2 \mathrm{H}_{2} \mathrm{O}+\mathrm{CO}_{2}
\end{gathered}
$$

The aim of this study was to investigate manganese recovery from spent batteries by sulfuric acid leaching in the presence of activated carbon powder as a reducing agent. The recovery of zinc from spent batteries was also indicated. The effects of sulfuric acid molarity, activated carbon powder amount, temperature and time were investigated.

\section{EXPERIMENTAL}

The different brand AA and AAA sized zinc-carbon and alkaline batteries disposed of Eskisehir Osmangazi University battery collection bins in Eskisehir, Turkey were used in this study. The batteries were dismantled by a laboratory hammer crusher. The crushed batteries were dry screened by a $2 \mathrm{~mm}$ sieve to remove manually steel cases, plastics and papers. 
Composition of the AA and AAA sized zinc-carbon and alkaline battery cells is $55.3 \%$ battery powder, $28.94 \%$ steel cases, $6.12 \%$ papers and $2.25 \%$ plastics.

The battery powder was put into oven at $105 \pm 5{ }^{\circ} \mathrm{C}$ for $24 \mathrm{~h}$. The moisture content of the battery powder was found to be $7.4 \%$. The dried battery powder was mixed carefully to ensure the homogeneity. The battery powder was ground for $30 \mathrm{~min}$ in a laboratory Bond ball mill. The particle size distribution of the battery powder was determined by a particle size analyzer (PSA) ${ }^{21}$. The $90 \%$ of ground battery powder was finer than $88 \mu \mathrm{m}$. All leaching tests were carried out using the ground battery powder.

Semi-quantitative analysis was carried out using a Philips PW-2404 X-Ray Fluorescence spectrometer (XRF). The elemental composition of the battery powder was $31.16 \%$ $\mathrm{Mn}, 28.52 \% \mathrm{Zn}, 2.59 \% \mathrm{~K}, 0.77 \% \mathrm{Fe}, 5.42 \% \mathrm{Cl}, 0.79 \% \mathrm{Si}$, $0.34 \% \mathrm{Al}, 0.02 \% \mathrm{Cr}$ and $0.02 \% \mathrm{Ti}$. The phases in the battery powder were determined using a Bruker AXS- $\mathrm{D}_{8}$ advance $\mathrm{X}$-ray diffractometer. Based on the XRD analysis, the major phases in the battery powder were simonkolleite $\left[\mathrm{Zn}_{5}(\mathrm{OH})_{8} \mathrm{Cl}_{2} \cdot \mathrm{H}_{2} \mathrm{O}\right]$, graphite $(\mathrm{C})$, manganese oxides $\left(\mathrm{MnO}_{2}\right.$, $\left.\mathrm{Mn}_{3} \mathrm{O}_{4}\right)$ and zinc oxide $(\mathrm{ZnO})$. The presence of $\mathrm{Cl}$ is due to ammonium chloride that is the electrolytes of zinc-carbon batteries $^{17,18,22,23}$. The most probable compounds identified by spectra were $\mathrm{ZnO}, \mathrm{MnO}_{2}, \mathrm{Mn}_{3} \mathrm{O}_{4}, \mathrm{C}$ and a zinc-chlorine compound in the unwashed battery powder and the same phases reduced a little for $\mathrm{Cl}$ complex in the washed battery powder.

Neutral leaching: Before acid leaching, the battery powder was washed with distilled water for $1 \mathrm{~h}$ at ambient temperature. $10 \mathrm{~g}$ of battery powder was added to $500 \mathrm{~mL}$ distilled water in a beaker (a liquid/solid ratio of 50:1) and the pulp was stirred with a magnetic stirrer at $400 \mathrm{rpm}$. After $1 \mathrm{~h}$, the slurry was filtered and then dried in the oven at $105 \pm 5^{\circ} \mathrm{C}$ for $24 \mathrm{~h}$. The final solution $\mathrm{pH}$ was found around 8.7 using a digital $\mathrm{pH}$ meter (Hach, 40d). The phase changes in the washed battery powder were examined using XRD before (unwashed) and after (washed) neutral leaching. Fig. 1 shows the phase differences between washed and unwashed battery powders.

Quantitative analysis: After neutral leaching, a quantitative analysis of the battery powder was also performed in $250 \mathrm{~mL}$ Erlenmeyer flask at $70{ }^{\circ} \mathrm{C}$. The stirring speed was kept constant at $200 \mathrm{rpm} .2 \mathrm{~g}$ of the battery powder was dissolved in $100 \mathrm{~mL}$ of $3 \mathrm{M}$ sulfuric acid solution. $1 \mathrm{~g}$ of oxalic acid was added to the flask as a reducing agent. A glass condenser was fitted to the Erlenmeyer flask to prevent evaporation.

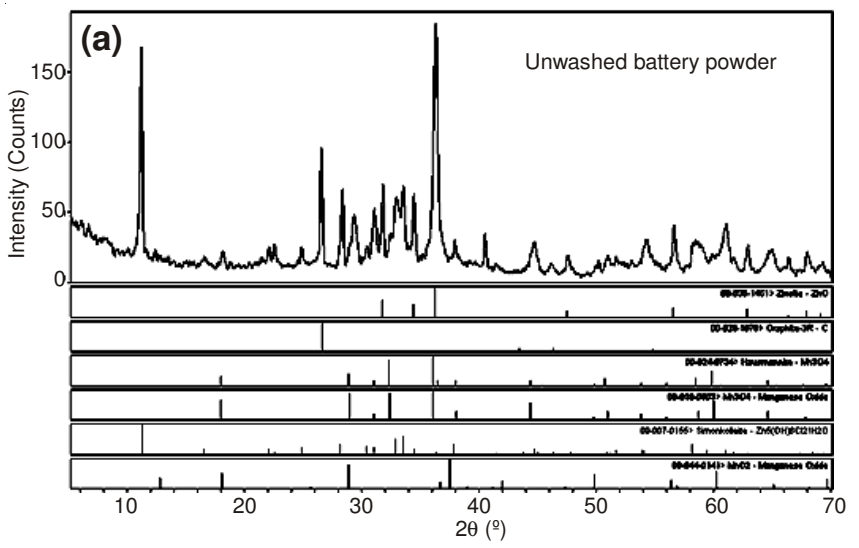

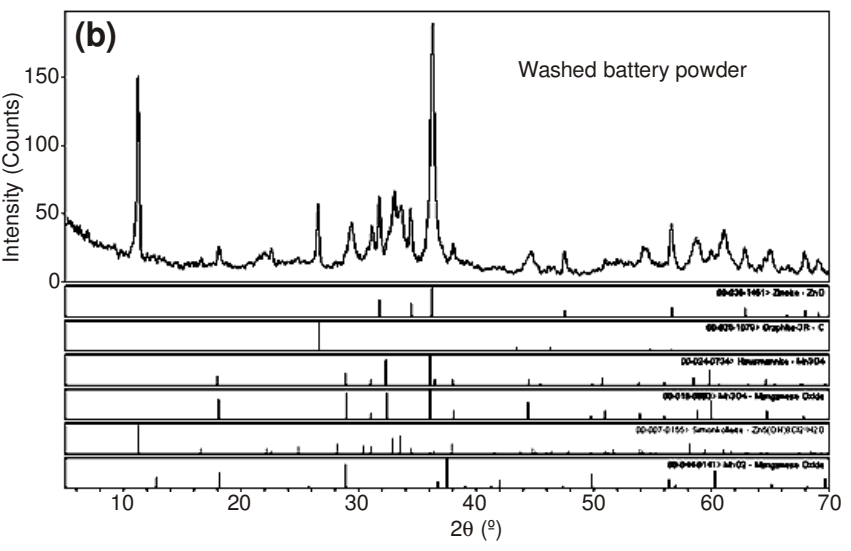

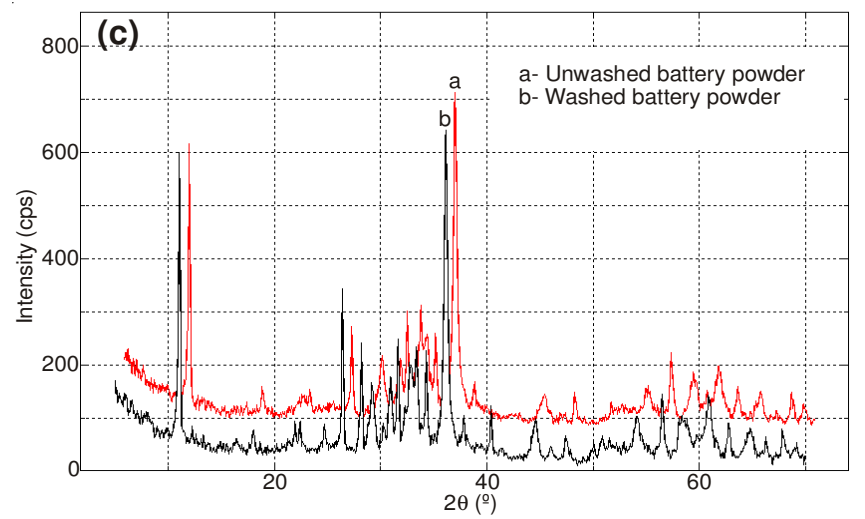

Fig. 1. XRD spectras of battery powders a) unwashed, b) washed (after neutral leaching) and c) comparision of washed and unwashed battery powders

After $5 \mathrm{~h}$ of leaching, the sample was filtered and the residue was washed with $5 \%$ nitric acid. The filtered solution was diluted to $250 \mathrm{~mL}$ with distilled water in a volumetric flask. Quantitative analyses of dissolved manganese and zinc in the sample were carried out using a Thermo scientific spectra 3000 atomic absorption spectrometer (AAS). The results of the quantitative analyses were $34.75 \% \mathrm{Mn}$ and $34.05 \% \mathrm{Zn}^{17,18}$. All of the chemicals used in this study were of analytical grade (Merck).

Reductive acid leaching experiments: For each experiment, $100 \mathrm{~mL}$ of different sulfuric acid concentrations $(0.5$ $\mathrm{M}, 0.75 \mathrm{M}$ and $1.0 \mathrm{M}$ ) and $5 \mathrm{~g}$ of battery powder were used to dissolve the manganese and zinc in the battery powder using different amount of activated carbon powder (1, 2 and $3 \mathrm{~g}$ ). The leaching temperature was changed from 40 to $80^{\circ} \mathrm{C}$ and leaching time from 1 to $3 \mathrm{~h}$. Leaching experiments were conducted inside a $250 \mathrm{~mL}$ Pyrex reactor equipped with a temperature-controlled circulating water bath. Cole Palmer mechanical stirrer was used. The stirring speed was kept constant for all the reductive acid leaching at $400 \mathrm{rpm}$. The experimental set up photograph used in experiments is shown in Fig. 2. The levels of the leaching variables are given in Table- 1 .

The four-factor central composite design techniques were used for process statistical analysis and modeling ${ }^{24}$. Using the data of reductive acid leaching experiments, the regression equation for manganese dissolution was calculated and the main interaction coefficients were determined. The following regression equation was used: 


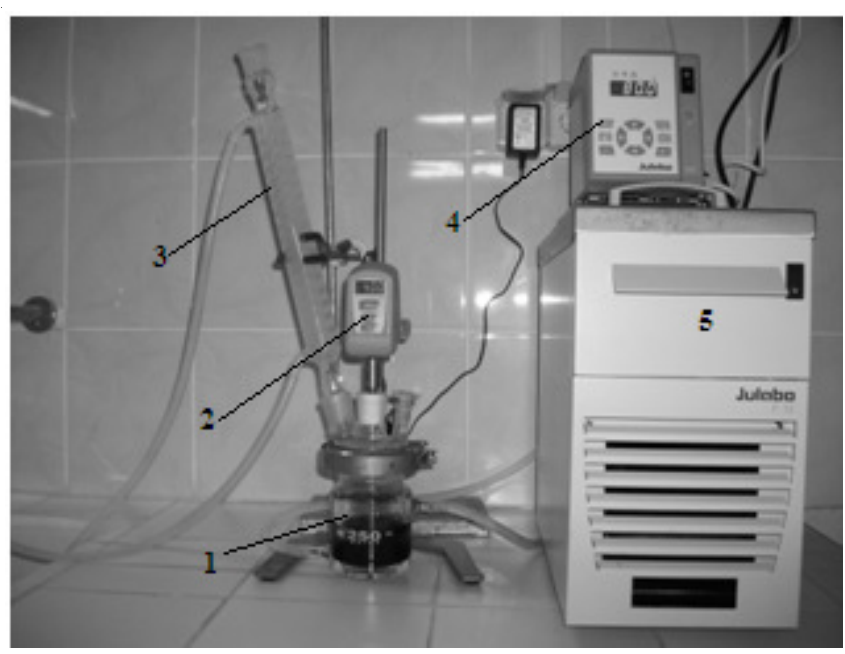

Fig. 2. Experimental set-up (1- Reactor, 2- Mechanical stirrer, 3- Glass condenser, 4- Temperature controller, 5- Circulating water bath)

\begin{tabular}{llccc}
\multicolumn{5}{c}{ TABLE-1 } \\
LEVELS OF VARIABLES INVESTIGATED IN THE \\
REDUCTIVE LEACHING EXPERIMENTS \\
\cline { 3 - 5 } Code & \multirow{2}{*}{ Variables } & \multicolumn{4}{c}{ Level } \\
\hline $\mathrm{X}_{1}$ & Molarity of sulfuric acid (M) & 0.5 & 0.75 & 1.0 \\
$\mathrm{X}_{2}$ & Amount of activated carbon powder $(\mathrm{g})$ & 1 & 2 & 3 \\
$\mathrm{X}_{3}$ & Temperature $\left({ }^{\circ} \mathrm{C}\right)$ & 40 & 60 & 80 \\
$\mathrm{X}_{4}$ & Time (h) & 1 & 2 & 3 \\
\hline$-1:$ low level; +1: high level; 0: base level; liquid/solid ratio: $20 / 1$ \\
$(\mathrm{~mL} / \mathrm{g})$
\end{tabular}

$$
\begin{gathered}
Y=b_{o}+b_{1} X_{1}+b_{2} X_{2}+b_{3} X_{3}+b_{4} X_{4}+b_{11} X_{1}^{2}+b_{22} X_{2}^{2}+ \\
b_{33} X_{3}^{2}+b_{44} X_{4}^{2}+b_{12} X_{1} X_{2}+b_{13} X_{1} X_{3}+b_{14} X_{1} X_{4}+ \\
b_{23} X_{2} X_{3}+b_{24} X_{2} X_{4}+b_{34} X_{3} X_{4}
\end{gathered}
$$

where, $\mathrm{Y}$ is a recovery efficiency of response variable; $\mathrm{b}_{(\mathrm{i})}$ are regression coefficients for linear effects; $\mathrm{b}_{(\mathrm{ik})}$ are the regression coefficient for quadratic effects and $\mathrm{X}_{(\mathrm{i})}$ are coded experimental levels of variables.

After reductive leaching, the battery powder in the reactor was filtered with Whatman 42 filter paper and the residue was washed with distilled water. For the AAS analyses, $10 \mathrm{~mL}$ of filtered solution was used. The recoveries of zinc and manganese in the reductive leaching process were calculated using the following equation:

$$
\mathrm{R}_{\mathrm{d}}=\left[\mathrm{C}_{1} / \mathrm{C}_{0}\right] \times 100
$$

where, $\mathrm{R}_{\mathrm{d}}$ is the dissolution ratio (\%), $\mathrm{C}_{1}$ is the instrumental analyses result for zinc and manganese at the end of the reductive leaching process $(\%), \mathrm{C}_{0}$ is the zinc and manganese quantitative analysis results (i.e. $34.05 \% \mathrm{Zn}$ and $34.75 \% \mathrm{Mn}$ ).

\section{RESULTS AND DISCUSSION}

Results of reductive acid leaching experiments: Table- 2 shows the coded variables for central composite design technique and results of the reductive acid leaching experiments. As can be seen from Table-2, the manganese recovery changed from 44.17 to $86.39 \%$ and the zinc recovery changed from 70.28 to $90.95 \%$. The maximum manganese recovery conditions were determined as $1 \mathrm{M}$ of sulfuric acid concentration,

\begin{tabular}{|c|c|c|c|c|c|c|c|c|c|}
\hline \multirow{2}{*}{ Run no. } & \multicolumn{3}{|c|}{ Variables } & \multirow[b]{2}{*}{$\mathrm{X}_{4}(\mathrm{~h})$} & \multicolumn{2}{|c|}{ Mn recovery $(\%)$} & \multicolumn{2}{|c|}{$\mathrm{Zn}$ recovery $(\%)$} & \multirow[t]{2}{*}{$\mathrm{pH}$} \\
\hline & $\mathrm{X}_{1}(\mathrm{M})$ & $X_{2}(g)$ & $\mathrm{X}_{3}\left({ }^{\circ} \mathrm{C}\right)$ & & Observed & Predicted & Observed & Predicted & \\
\hline 1 & -1 & -1 & -1 & -1 & 44.17 & 44.95 & 71.46 & 71.62 & 1.45 \\
\hline 2 & 1 & -1 & -1 & -1 & 50.08 & 50.765 & 72.72 & 73.54 & 0.60 \\
\hline 3 & -1 & 1 & -1 & -1 & 49.29 & 50.02 & 70.49 & 70.73 & 1.25 \\
\hline 4 & 1 & 1 & -1 & -1 & 61.12 & 62.76 & 70.28 & 72.35 & 0.62 \\
\hline 5 & -1 & -1 & 1 & -1 & 66.48 & 63.56 & 77.24 & 77.11 & 1.52 \\
\hline 6 & 1 & -1 & 1 & -1 & 66.79 & 69.14 & 77.95 & 79.96 & 0.62 \\
\hline 7 & -1 & 1 & 1 & -1 & 60.06 & 61.77 & 73.95 & 75.67 & 1.62 \\
\hline 8 & 1 & 1 & 1 & -1 & 77.15 & 74.27 & 79.41 & 78.24 & 0.65 \\
\hline 9 & -1 & -1 & -1 & 1 & 46.56 & 48.72 & 74.09 & 75.84 & 1.19 \\
\hline 10 & 1 & -1 & -1 & 1 & 59.17 & 59.72 & 80.12 & 79.31 & 0.50 \\
\hline 11 & -1 & 1 & -1 & 1 & 59.14 & 59.04 & 78.79 & 77.67 & 1.37 \\
\hline 12 & 1 & 1 & -1 & 1 & 74.76 & 76.96 & 80.12 & 80.84 & 0.55 \\
\hline 13 & -1 & -1 & 1 & 1 & 66.11 & 66.72 & 80.59 & 79.41 & 1.63 \\
\hline 14 & 1 & -1 & 1 & 1 & 78.94 & 77.49 & 83.47 & 83.82 & 0.75 \\
\hline 16 & 1 & 1 & 1 & 1 & 86.39 & 87.86 & 84.08 & 84.82 & 0.77 \\
\hline 17 & -1 & 0 & 0 & 0 & 63.48 & 61.85 & 83.53 & 82.29 & 0.89 \\
\hline 18 & 1 & 0 & 0 & 0 & 78.19 & 73.61 & 90.08 & 85.31 & 0.87 \\
\hline 19 & 0 & -1 & 0 & 0 & 72.26 & 69.45 & 88.72 & 85.73 & 0.83 \\
\hline 20 & 0 & 1 & 0 & 0 & 80.58 & 77.17 & 88.79 & 85.78 & 0.97 \\
\hline 21 & 0 & 0 & -1 & 0 & 81.15 & 72.47 & 87.96 & 84.09 & 1.49 \\
\hline 22 & 0 & 0 & 1 & 0 & 84.75 & 87.22 & 90.95 & 88.82 & 0.69 \\
\hline 23 & 0 & 0 & 0 & -1 & 69.04 & 66.91 & 87.02 & 81.27 & 0.88 \\
\hline 24 & 0 & 0 & 0 & 1 & 79.66 & 75.58 & 86.93 & 86.67 & 0.97 \\
\hline 25 & 0 & 0 & 0 & 0 & 71.43 & 76.04 & 83.58 & 87.46 & 0.84 \\
\hline 26 & 0 & 0 & 0 & 0 & 71.04 & 76.04 & 83.17 & 87.46 & 0.97 \\
\hline 27 & 0 & 0 & 0 & 0 & 71.97 & 76.04 & 82.47 & 87.46 & 0.83 \\
\hline 28 & 0 & 0 & 0 & 0 & 71.15 & 76.04 & 82.65 & 87.46 & 0.91 \\
\hline
\end{tabular}
$3 \mathrm{~g}$ of activated carbon powder, $80^{\circ} \mathrm{C}$ of leaching temperature

TABLE-2

RESULTS OF REDUCTIVE ACID LEACHING EXPERIMENTS 
and $3 \mathrm{~h}$ of leaching time. Under these conditions, the manganese recovery was $86.39 \%$ and the zinc recovery was $84.08 \%$. At the central points, zinc recovery changed from 82.57 to $83.48 \%$, while manganese recovery changed from 71.04 to $71.97 \% . \mathrm{pH}$ values of the solutions after reductive acid leaching experiments changed from 0.55 to 1.85 . As can be seen from Table-2, to change form of manganese from manganese oxides to manganese sulfate; a strong acidic media and a reductant must be used. However, zinc oxide can be easily dissolved and reduced to zinc sulfate in the absence of a reductant in acidic media.

The following model equation representing the manganese recovery $\left(\mathrm{Y}_{\mathrm{Mn}}\right)$ was described as functions sulfuric acid molarity $\left(\mathrm{X}_{1}\right)$, activated carbon powder amount $\left(\mathrm{X}_{2}\right)$, temperature $\left(\mathrm{X}_{3}\right)$ and time $\left(\mathrm{X}_{4}\right)$ for coded units as given below:

$\mathrm{Y}_{\mathrm{Mn}}=76.049+5.873 \mathrm{X}_{1}+3.861 \mathrm{X}_{2}+7.377 \mathrm{X}_{3}+4.340 \mathrm{X}_{4}-$ $8.316 \mathrm{X}_{1}^{2}-2.731 \mathrm{X}_{2}^{2}+3.798 \mathrm{X}_{3}^{2}-4.801 \mathrm{X}_{4}^{2}+1.731 \mathrm{X}_{1} \mathrm{X}_{2}-$

$0.057 \mathrm{X}_{1} \mathrm{X}_{3}+1.296 \mathrm{X}_{1} \mathrm{X}_{4}-1.717 \mathrm{X}_{2} \mathrm{X}_{3}+1.311 \mathrm{X}_{2} \mathrm{X}_{4}-$

$$
0.152 \mathrm{X}_{3} \mathrm{X}_{4}
$$

The statistical significance of eqn. 5 was controlled by F-test and the analysis of variance (ANOVA) for response surface model is shown in Table-3. The $p$ value for this model is less than 0.001. This explains that the model is considered to be statistically significant ${ }^{25}$.

TABLE-3

ANALYSIS OF VARIANCE (ANOVA) OF THE RESPONSE SURFACE MODEL TO PREDICT MANGANESE RECOVERY

\begin{tabular}{lcrrrrc}
\hline Source & DF & \multicolumn{1}{c}{ Seq SS } & \multicolumn{1}{c}{ Adj SS } & Adj MS & \multicolumn{1}{c}{ F } & P \\
\hline Regression & 14 & 3229.53 & 3229.53 & 230.681 & 10.76 & 0.000 \\
Linear & 4 & 2208.20 & 2208.20 & 552.051 & 25.75 & 0.000 \\
Square & 4 & 871.36 & 871.36 & 217.839 & 10.16 & 0.001 \\
Interaction & 6 & 149.97 & 149.97 & 24.995 & 1.17 & 0.381 \\
Residual Error & 13 & 278.75 & 278.75 & 21.442 & & \\
Lack-of-Fit & 10 & 278.23 & 278.23 & 27.823 & 161.18 & 0.001 \\
Pure Error & 3 & 0.52 & 0.52 & 0.173 & & \\
\hline Total & 27 & 3508.28 & & & & \\
\hline
\end{tabular}

The observed values were evaluated utilizing Minitab Trail 15 software package. The regression equations can be represented for manganese in eqn. (5). The coefficient of determination was found to be 0.92 , which means that the model could explain $92 \%$ of the total variations in the system. The high value of $\mathrm{R}^{2}$ indicates that the eqn. (5) is capable of representing the system under the given experimental condition as shown in Fig. 3.

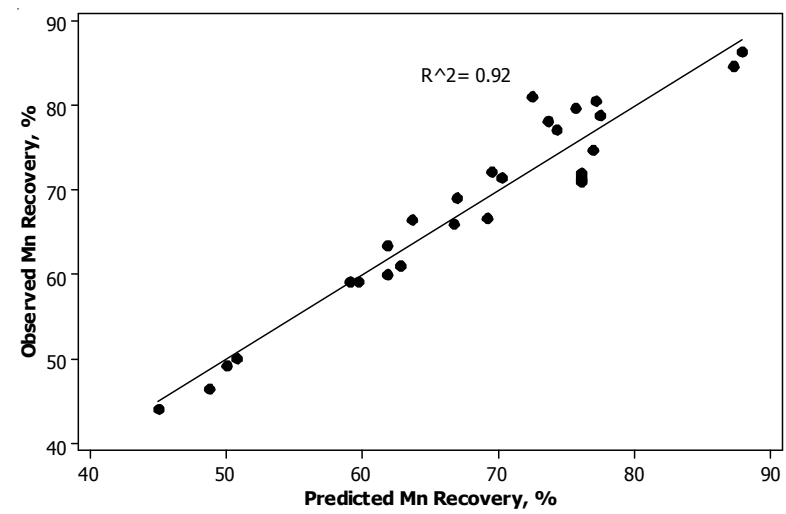

Fig. 3. Plot of observed versus predicted values for manganese recovery
In order to realize better understanding of the results on manganese recovery, the predicted models are represented in Figs. (4-9) using 3D response surface plots. Fig. 4 shows the response surface relation between molarity of sulfuric acid $\left(\mathrm{X}_{1}\right)$ and amount of activated carbon powder $\left(\mathrm{X}_{2}\right)$ on manganese recovery at center level of temperature $\left(\mathrm{X}_{3}\right)$ and time $\left(\mathrm{X}_{4}\right)$. It was clear that the maximum amount of manganese recovery was achieved at central level of sulfuric acid concentration and the highest level of activated carbon powder values.

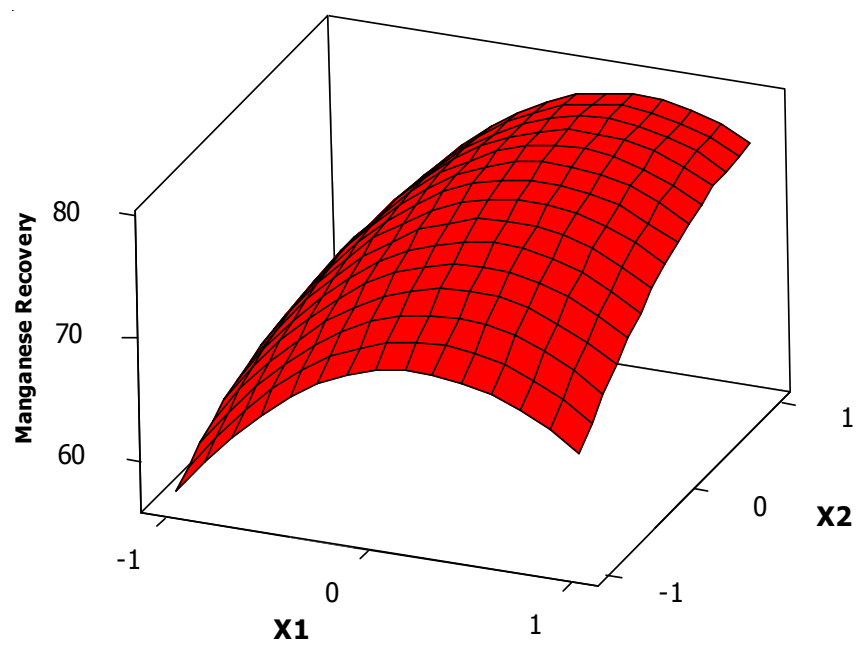

Fig. 4. Response surface plots showing the effect of molarity of sulfuric acid $\left(\mathrm{X}_{1}\right)$ and amount of activated carbon powder $\left(\mathrm{X}_{2}\right)$ on manganese recovery

Fig. 5 shows the response surface relationship between sulfuric acid molarity $\left(\mathrm{X}_{1}\right)$ and temperature $\left(\mathrm{X}_{3}\right)$ on manganese recovery at center level of activated carbon powder $\left(\mathrm{X}_{2}\right)$ and time $\left(\mathrm{X}_{4}\right)$. It was obvious that the highest manganese recovery was achieved at central levels of sulfuric acid concentration and the highest level of temperature values.

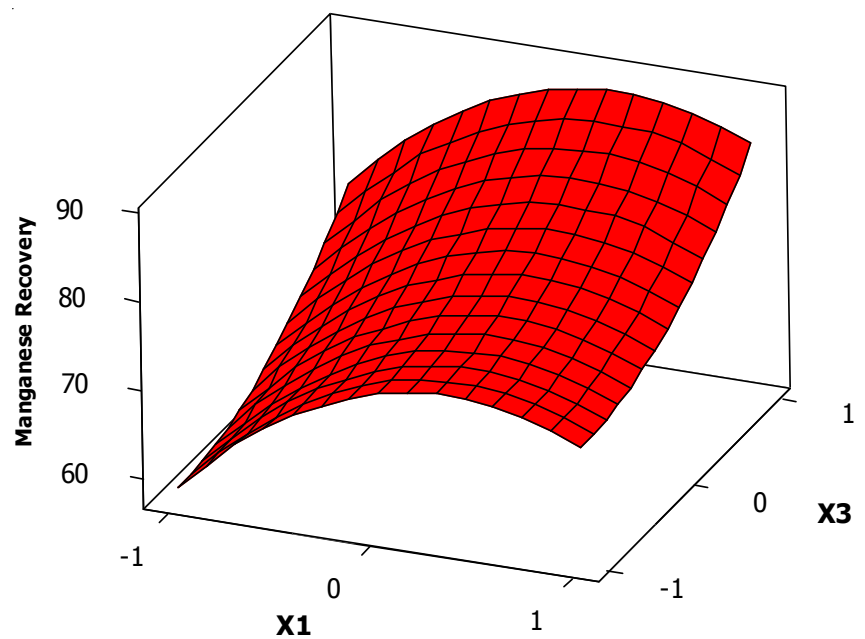

Fig. 5. Response surface plots showing the effect of sulfuric acid molarity $\left(\mathrm{X}_{1}\right)$ and temperature $\left(\mathrm{X}_{3}\right)$ on manganese recovery

Fig. 6 shows the response surface relation between the molarity of sulfuric acid $\left(\mathrm{X}_{1}\right)$ and time $\left(\mathrm{X}_{4}\right)$ on manganese recovery at center level of activated carbon powder $\left(\mathrm{X}_{2}\right)$ and temperature $\left(\mathrm{X}_{3}\right)$. It was observed that the maximum amount 
of manganese recovery was achieved at central level of sulfuric acid concentration and the highest level of time values.

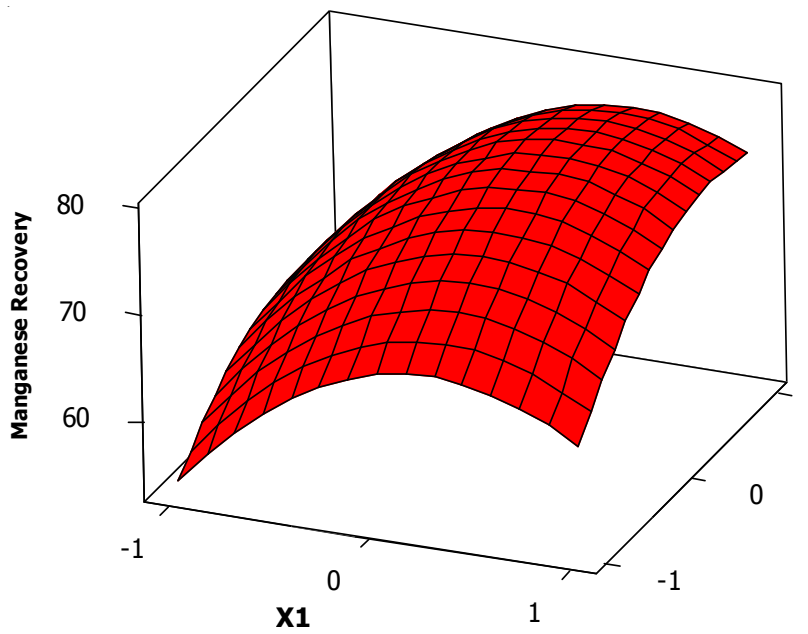

Fig. 6. Response surface plots showing the effect of sulfuric acid molarity $\left(\mathrm{X}_{1}\right)$ and time $\left(\mathrm{X}_{4}\right)$ on manganese recovery

Fig. 7 shows the response surface relationship between activated carbon powder $\left(\mathrm{X}_{2}\right)$ and temperature $\left(\mathrm{X}_{3}\right)$ on manganese recovery at center level of sulfuric acid molarity $\left(\mathrm{X}_{1}\right)$ and time $\left(\mathrm{X}_{4}\right)$. It was obvious that the highest manganese recovery was achieved at the central level of activated carbon powder and the highest temperature values.



1

Fig. 7. Response surface plots showing the effect of amount of activated carbon powder $\left(\mathrm{X}_{2}\right)$ and temperature $\left(\mathrm{X}_{3}\right)$ on manganese recovery

Fig. 8 shows the response surface relation amount of activate carbon powder $\left(\mathrm{X}_{2}\right)$ and time $\left(\mathrm{X}_{4}\right)$ on manganese recovery at center level of sulfuric acid molarity $\left(\mathrm{X}_{1}\right)$ and temperature $\left(\mathrm{X}_{3}\right)$. It was clear that the maximum amount of manganese recovery was achieved at the highest levels of activated carbon powder and time values.

Fig. 9 shows the response surface relation temperature $\left(\mathrm{X}_{3}\right)$ and time $\left(\mathrm{X}_{4}\right)$ on manganese recovery at center level of sulfuric acid molarity $\left(\mathrm{X}_{1}\right)$ and activated carbon powder $\left(\mathrm{X}_{2}\right)$. It was obvious that the maximum amount of manganese recovery was achieved at the highest levels of temperature and time values.

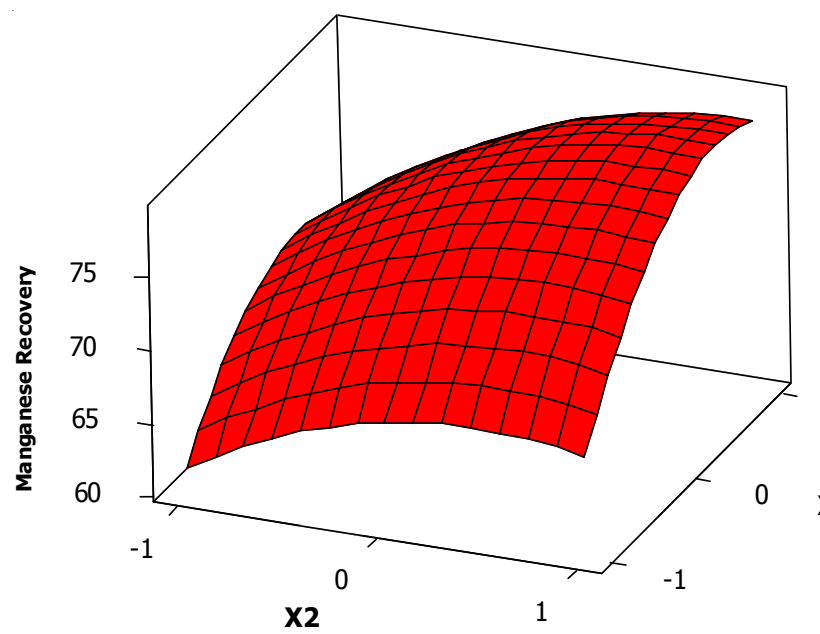

Fig. 8. Response surface plots showing the effect of amount of activated carbon powder $\left(\mathrm{X}_{2}\right)$ and time $\left(\mathrm{X}_{4}\right)$ on manganese recovery

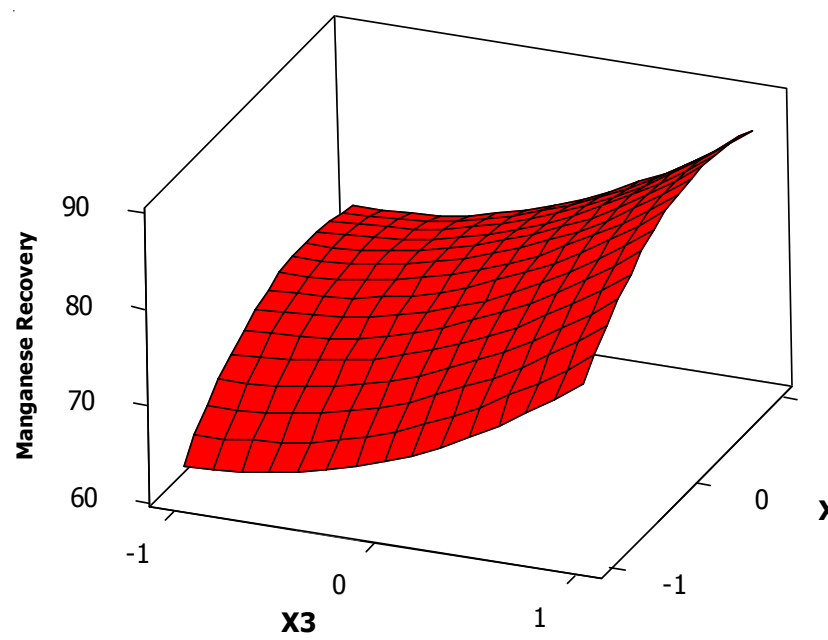

Fig. 9. Response surface plots showing the effect of temperature $\left(\mathrm{X}_{3}\right)$ and time $\left(\mathrm{X}_{4}\right)$ on manganese recovery

\section{Conclusion}

In this study, the effects of sulfuric acid, activated carbon powder, temperature and time on manganese recovery from AA and AAA sized spent zinc-carbon and alkaline batteries were investigated using central composite design technique. The maximum manganese recovery conditions were obtained in $1 \mathrm{M}$ sulfuric acid, $3 \mathrm{~g}$ of activated carbon powder, $80{ }^{\circ} \mathrm{C}$ of leaching temperature and $3 \mathrm{~h}$ of leaching time. Under these conditions, the manganese recovery was $86.39 \%$ and $\mathrm{pH}$ value of the solution was 0.77 . The zinc recovery in optimum conditions was $84.08 \%$. Second-order statistical model, representing the manganese recovery expressed as a function of these four variables, was evaluated by Minitab 15 Trail software package. A statistical analysis was carried out to determine the effects of the individual variables as well as their combined interactive effects on manganese recovery. The results showed that the effects of variables were significantly important. The observed values of manganese recoveries using model equation were found to be in a good agreement with the predicted values $\left(\mathrm{R}^{2}=0.92\right)$.

Since this study showed that pure activated carbon powder was very good reductant for manganese recovery, the usability of industrial waste carbon sources and the efficiency of selective 
precipitation of manganese from the reductive acid leach solutions will be investigated in further work.

\section{ACKNOWLEDGEMENTS}

This work was supported by Research Projects Funding Unit of Eskisehir Osmangazi University (Project no: BAP 2009/15018) in Eskisehir, Turkey. The Authors are grateful to Mrs. Mujesira Vukancic from Western Australian School of Mines for her assistance.

\section{REFERENCES}

1. A.L. Salgado, A.M.O. Veloso, D.D. Pereira, G.S. Gontijo, A. Salum, and M.B. Mansur, J. Power Sour., 115, 367 (2003).

2. A.M. Bernardes, D.C.R. Espinosa and J.A.S. Tenorio, J. Power Sour, 130, 291 (2004).

3. D.C.R. Espinosa, A.M. Bernardes and J.A.S. Tenorio, J. Power Sour., 135, 311 (2004).

4. S. Frohlich and D. Sewing, J. Power Sour, 57, 27 (1995).

5. D. Martin, M.A. Garcia, G. Diaz and J. Falgueras, A New Zinc Solvent Extraction Application: Spent Domestic Batteries Treatment Plant. International Solvent Extraction Conference (ISEC'99). Society of Chemical Industry, Barcelona, Spain (2001).

6. S.C. Das, P.K. Sahoo and P.K. Rao, Hydrometallurgy, 8, 35 (1982).

7. C. Abbruzzese, Hydrometallurgy, 24, 85 (1990).

8. X. Tian, X. Wen, C. Yang, Y. Liang, Z. Pi and Y. Wang, Hydrometallurgy, 100, 157 (2010).

9. M. Trifoni, F. Vevglio, G. Taglieri and L. Toro, Minerals Engg., 13, 217 (2000).

10. M. Trifoni, L. Toro and F. Veglio, Hydrometallurgy, 59, 1 (2001).
11. F. Pagnanelli, G. Furlani, P. Valentini, F. Veglio and L. Toro, Hydrometallurgy, 75, 157 (2004).

12. G. Furlani, E. Moscardini, F. Pagnanelli, F. Ferella, F. Veglio and L. Toro, Hydrometallurgy, 99, 115 (2009).

13. F. Veglio, I. Volpe, M. Trifoni and L. Toro, Ind. Engg. Chem. Res., 39, 2947 (2000).

14. F. Veglio and L. Toro, Hydrometallurgy, 36, 215 (1994).

15. R.N. Sahoo, P.K. Naik and S.C. Das, Hydrometallurgy, 62, 157 (2001).

16. E. Sayilgan, T. Kukrer, F. Ferella, A. Akcil, F. Veglio and M. Kitis, Hydrometallurgy, 97, 73 (2009).

17. M. Kaya and S. Kursunoglu, Recycling of Spent AA and AAA Sized Zinc-carbon and Alkaline Batteries. 9th International Conference on Clean Technologies for the Mining Industry, Santiago, Chile, April, 10-12 (2011).

18. M. Kaya and S. Kursunoglu, A Review of the Current Hydrometallurgical Recycling of Spent AA and AAA Sized Zn-c and Alkaline Batteries. European Metallurgical Conference (EMC-2011), Dusseldorf, Germany, June, 26-29 (2011).

19. E. Sayilgan, T. Kukrer, N.L. Yigit, G. Civelekoglu and M. Kitis, J. Hazard., 173, 137 (2010).

20. A. Biswal, K. Sanjay, M.K. Ghosh, T. Subbaiah and B.K. Mishra, Preparation and Characterization of Electrolytic Manganese Dioxide (EMD) was prepared from manganese cake-A by Product of Manganese Nodule Processing. Hydrometallurgy, Hydrom-03419 (2011).

21. http://www.malvern.com/common/downloads/campaign/MRK141201.pdf (2000).

22. C.C.B.M. De Souza, D.C. Oliveira and J.A.S. Tenorio, J. Power Sour., 103, 120 (2001).

23. F. Ferella, I. de Michelis and F. Veglio, J. Power Sour., 183, 805 (2008).

24. D.C. Montgomery, Design and Analysis of Experiments, Wiley, New York, edn. 5 (2001).

25. P. Karimi, N. Abdollah, N. Aslan, M. Noaparast and Z. Shafaei, Miner. Proc. Extract. Metal. Rev., 32, 1 (2011). 